answered. In this communication we have been able merely to outline the problems involved and the progress made towards solving some of them. It is evident that this is still a new field of study which can make a contribution to the understanding not only of gastroenterological but also of general medical and pharmacological problems.

\section{References}

Aries, V., Crowther, J. S., Drasar, B. S., Hill, M. J., and Williams, R. E. O. (1969). Bacteria and the aetiology of cancer of the large bowel. Gut, 10, 334-335.

Bircher, J., Müller, J., Guggenheim, P., and Haemmerli, U. P. (1966). Treatment of chronic portal-systemic encephalopathy with lactulose. Lancet, 1, 890-893.

Brown, C. L., Hill, M. J., and Richards, P. (1971). Bacterial ureases in uraemic men. Lancet, 2, 406-408.

Elkington, S. G., Floch, M. H., and Conn, H. O. (1969). Lactulose in the treatment of chronic portal systemic encephalopathy. New Engl. J. Med., 281, 408-412.

Evans, W. B., Aoyagi, T., and Summerskill, W. H. J. (1966). Gastrointestinal urease in man. II. Urea hydrolysis and ammonia absorption in upper and lower gut lumen and the effect of neomycin. Gut, 7, 635-639.

Goddard, P., and Hill, M. J. (1973). The dehydrogenation of the steroid nucleus by human gut bacteria. Trans. biochem. Soc., 1, 1113-1115.

Hardcastle, J. D., and Wilkins, J. L. (1970). The action of sennosides and related compounds on human colon and rectum. Gut, 11, 1038-1042.

Hill, M. J. (1971a). Gut bacteria steroids and cancer of the large bowel. In Some Implications of Steroid Hormones in Cancer, edited by D. C. Williams and M. H. Briggs, pp. 94-106. Heinemann, London.

Hill, M. J. (1971b). The effect of some factors on the faecal concentration of acid steroids, neutral steroids and urobilins. $J$. Path., 104, 239-245.

Hill, M. J. (1974). Bacteria and the etiology of colon cancer. Cancer (Philad.), 34,815-818.

Hill, M. J., Drasar, B. S., Aries, V., Crowther, J. S., Hawksworth, G. and Williams, R. E. O. (1971). Bacteria and aetiology of cancer of the large bowel. Lancet, 1, 95-100.
Hill, M. J., Drasar, B. S., Goddard, P., Peach, S., Williams, R. E. O., Meade, T. W., Cox, A., Simpson, J. E. P., and Morson, B. (1974). Bacteria, bile acids, and the aetiology of large bowel. cancer. J. med. Microbiol., 7, vii-viii.

Jones, E. A., Smallwood, R. A., Craigie, A., and Rosenoer, V. M (1969). The enterohepatic circulation of urea nitrogen. Clin. Sci., 37, 825-836.

Levensen, S. M., Crowley, L. V., Herowitz, R. E., and Malm, O. J. (1959). The metabolism of carbon-labelled urea in the germfree rat. J. biol. Chem., 234, 2061-2062.

Neale, G. (1971). Disaccharidase deficiencies. J. clin. Path., 24, Suppl. (Roy. Coll. Path.) 5, 22-28.

Peach, S., Fernandez, F., Johnson, K., and Drasar, B. S. (1974). The non-sporing anaerobic bacteria in human faeces. $J$. med. Microbiol., 7, 213-221

Riddell, A. G. (1955). Ammonia intoxication in surgical patients. Ann. roy. Coll. Surg. Engl., 17, 319-329.

Samuelsson, B. (1960). On the mechanism of the biological formation of deoxycholic acid from cholic acid. J. biol. Chem., 235, 361-366.

Schenker, S., McCandless, D. W., Brophy, E., and Lewis, M. S. (1967). Studies on the intracerebral toxicity of ammonia. J. clin. Invest., 46, 838-848.

Smith, R. L. (1966). The biliary excretion and enterohepatic circulation of drugs and other organic compounds. Fortschr. Arugneimittelforsch., 9, 300-359.

Spatz, M., Smith, D. W. E., McDaniel, E. G., and Laqueur, G. L. (1967). Role of intestinal micro-organisms in determining cycasin toxicity. Proc. Soc. exp. Biol. (N.Y.), 124, 691-697.

Summerskill, W. H. J. (1970). Ammonia metabolism in the gastrointestinal tract. Progr. Gastroent., 2, 276-287.

Walker, J. G., En.lyn-Williams, A., Craigie, A., Rosenoer, V. M., Agnew, J., and Sherlock, S. (1965). Treatment of chronic portal-systemic encephalopathy by surgical exclusion of the colon. Lancet, 2, 861-866.

Walser, M., and Bodenlos, L. J. (1959). Urea metabolism in man. J. clin. Invest., 38, 1617-1626.

White, L. P., Phear, E. A., Summerskill, W. H. J., and Sherlock, S. (1955). Ammonium tolerance in liver disease: observations based on catheterization of the hepatic veins. J. clin. Invest., 34, 158168.

Wolpert, E., Phillips, S. F., and Summerskill, W. H. J. (1971). Transport of urea and ammonia production in the human colon. Lancet, 2, 1387-1390.

Wynder, E. L., and Reddy, B. S. (1974). Metabolic epidemiology of colorectal cancer. Cancer (Philad.), 34, 801-806.

\title{
Absorption and secretion by the colon
}

\author{
JOHN H. CUMMINGS
}

From the Medical Research Council Gastroenterology Unit, Central Middlesex Hospital, London

Various aspects of colonic absorptive function in man have been dealt with in a number of reviews (Phillips, 1969; Turnberg, 1970; Wrong, 1971; Shields, 1972; Sladen, 1972; Edmonds and Pilcher, 1972).

\section{Electrolytes and Water}

The role which the colon plays in conserving water and electrolytes has been known for some time, deduced largely from a comparison of the volume and composition of ileostomy effluent with that of faeces and confirmed by perfusion of the colon in vivo. The quantity of these substances absorbed daily by the colon has, however, to be revised, since it has been shown that the flow of ileal contents into the colon each day is three times the normal volume of ileostomy effluent (Kanaghinis, Lubran, and Coghill,1963; Phillips and Giller, 1973). Fasting ileal flow rates, measured by slow intestinal 
perfusion techniques, have been reported by several groups and vary between 0.3 and $1.6 \mathrm{ml} / \mathrm{min}$ (Soergel, 1971; Phillips and Giller, 1973; RaskMadsen, 1973; Cummings, Milton-Thompson, Billings, Newman, and Misiewicz, 1974). After meals the flow rate in the ileum peaks to $4-8 \mathrm{ml} / \mathrm{min}$ giving an overall flow into the colon of $1500 \mathrm{ml} /$ day. The electrolyte composition of ileal contents varies little in health and is very similar in those diarrhoeal diseases where ileal flow has been shown to increase (Banwell, Pierce, Mitra, Brigham, Caranasos, Keimowitz, Fedson, Thomas, Gorbach, Sack, and Mondal, 1970; Banwell, Gorbach, Pierce, Mitra, and Mondal, 1971). The exceptions to this are congenital chloridorrhoea (Turnberg, 1971; Pearson, Sladen, Edmonds, Tavill, Wills, and McIntyre, 1973) and the Cronkhite-Canada syndrome (Johnson, Soergel, Hensley, Dodds, and Hogan, 1972) where bicarbonate concentrations are reduced.

When the daily load of water and electrolytes delivered to the colon is compared with their faecal excretion it is apparent that the normal colon absorbs $1350 \mathrm{ml}$ water, $200 \mathrm{~m}$-equiv sodium, 150 m-equiv chloride, and $60 \mathrm{~m}$-equiv bicarbonate each day. The amount of potassium entering and leaving the colon each day is about equal.

Sodium, the main cation entering the colon, is absorbed by active transport and is responsible for the large electrical gradient across the mucosa (Edmonds and Pilcher, 1972). Using colonic perfusion (Levitan, Fordtran, Burrows, and Ingelfinger, 1962; Shields and Miles, 1965; Devroede and Phillips, 1969) and other techniques, the colonic mucosa has been shown to absorb sodium from luminal concentrations as low as $15 \mathrm{~m}$-equiv/l and against a potential difference of $40 \mathrm{mV}$ (luminal side negative). Unlike in the jejunum, sodium absorption in the colon is not stimulated by glucose (Powell and Malawer, 1968; Billich and Levitan, 1969), bicarbonate (Devroede and Phillips, 1969) or amino acids (Grady, Duhamel, and Moore, 1970). Whilst active transport is the major pathway for sodium absorption it is possible that sodium movements may be coupled to hydrogen ion secretion as in the ileum (Turnberg, Bieberdorf, Morawski, and Fordtran, 1970) or that coupled non-electrogenic transport may occur (Binder and Rawlins, 1972). However, the failure of the luminal $\mathrm{pH}$ to fall during colonic perfusion studies where chloride has been replaced by sulphate is against the existence of a $\mathrm{Na}^{+} / \mathrm{H}^{+}$ exchange although faecal $\mathrm{pH}$ falls when sodium sulphate is taken by mouth (Down, Agostini, Murison, and Wrong, 1972; Bown, Sladen, Rousseau, Gibson, Clark, and Dawson, 1972).

Movement of water in the colon is passive and occurs in response to solute transport. As sodium is the main cation it closely parallels sodium movements. When net sodium transport is zero water absorption is minimal (Devroede and Phillips, 1969). This close relationship holds also during secretion into the colon induced by bile salts (Wingate, Krag, Mekhjian, and Phillips, 1973) and villous adenoma of the colon (Duthie and Atwell, 1963).

Potassium movements are mainly passive, occurring in response to electrochemical gradients. Potassium is secreted into isotonic saline solutions perfused through the colon (Levitan et al, 1962) and absorbed from perfusate containing more than 15 m-equiv/l of potassium (Devroede and Phillips, 1969). Edmonds and Godfrey (1970), on the basis of electrolyte movements and pd measurements in the rectum, suggest that there is also an active component to potassium movements, although Giller and Phillips (1972), after measuring right colonic pd during perfusion experiments, say that potassium movement is passive and entirely predictable from the $\mathrm{pH}$ using the Nernst equation. The various regions of the colon appear to handle potassium differently and this may be explained by the greater permeability of the proximal colon compared with that of the rectum (Billich and Levitan, 1969; Edmonds and Pilcher, 1972). Increased secretion of potassium into the colon was noted during perfusion of low $\mathrm{pH}$ solutions, which may alter permeability (Bown et al, 1972). The more restricted permeability of the distal colon and rectum may in part explain concentrations of potassium of up to 140 m-equiv/l that occur in normal stool water (Wrong, Metcalfe-Gibson, Morrison, $\mathrm{Ng}$, and Howard, 1965).

Strong evidence exists for a chloride-bicarbonate exchange system in the colon as occurs in the ileum. Chloride is absorbed from luminal solutions containing as little as $25 \mathrm{~m}$-equiv/l (Devroede and Phillips, 1969). More chloride than sodium is absorbed from equimolar solutions and the difference can invariably be accounted for by bicarbonate secretion. Replacement of chloride by sulphate in the perfusate inhibits bicarbonate secretion, and increased chloride absorption occurs at low luminal $\mathrm{pH}$, where bicarbonate secretion should be stimulated (Bown et al, 1972). Bicarbonate is secreted into the colon against electrochemical gradients. The role of carbonic anhydrase in this anion exchange in man is not clear but in several animal species this enzyme is present in high concentration in the caecum and right colon (Kuriaki and Magee, 1964; Maren, 1967; Carter and Parsons, 1968).

As already noted, regional differences in colonic function exist. Sodium flux rates in both directions in the rectum are reduced compared with data derived from colonic perfusion work (Edmonds 
and Pilcher, 1972), and, whilst the rectum is able to absorb salt and water, it is only at a reduced rate (Edmonds, 1971; Rask-Madsen, Hammersgaarel, and Knudsen, 1973). Furthermore the response of the colon to aldosterone differs between the left and right sides (Edmonds and Marriott, 1967). Devroede, Phillips, Code, and Lind (1971), measuring sodium insorption (mucosa-to-serosa flux), have shown that this is most rapid in the caecum and decreases progressively towards the rectum. This concept of regional differences finds some backing in clinical experience. In a review of colonic surgery by Gazet (1968) patients with right hemicolectomies were six times more likely to have significant diarrhoea subsequently than those who had a left hemicolectomy even after taking into account those with previous ileal disease.

Various hormones influence colonic electrolyte handling. Aldosterone stimulates colonic sodium and water absorption in a manner analogous to its effect on the renal tubule, although the colon does not 'escape' from this effect as does the kidney (Levitan and Ingelfinger, 1965; Wrong, 1968; Charron, Leme, Wilson, Ing, and Wrong, 1969). Patients with primary hyperaldosteronism have decreased $\mathrm{Na} / \mathrm{K}$ ratios in their stools (Richards, 1969), and the increase in rectal pd found in these patients, due to stimulation of sodium transport, has been used as a screening test in the diagnosis of this condition (Edmonds and Richards, 1970). Shields, Mulholland, and Elmslie (1966) and Shields, Miles, and Gilbertson (1968) have also demonstrated potassium secretion by the colon with aldosterone. Spironolactone blocks the effects of aldosterone (Elmslie, Mulholland, and Shields, 1966; Edmonds and Pilcher, 1972) whilst $9 \alpha$-fluorohydrocortisone also stimulates salt and water absorption (Levitan, 1967). Some doubt exists as to whether the other adrenal cortical hormones effect the colon (Duthie, Watts, de Dombal, and Goligher, 1964) but patients with raised plasma cortisol levels have decreased faecal $\mathrm{Na} / \mathrm{K}$ ratios (Charron et al, 1969; Richards, 1969). Angiotensin at low concentrations stimulates colonic sodium absorption (Davies, Munday, and Parsons, 1970; Hornych, Meyer, and Milliez, 1973) and Parsons and Munday (1972) have made a strong case for its role in normal colonic sodium metabolism. By contrast, antidiuretic hormone, when given to well hydrated subjects at 1 unit per hour, decreased salt and water absorption (Levitan and Mauer, 1966), and in vitro increases short-circuit current (Grady et al, 1970). Unlike their effect on the small intestine, both pentagastrin (Gingell, Davies, and Shields, 1968) and prostaglandin $F_{2_{\alpha}}$ (Cummings et al, 1974) fail to alter colonic electrolyte handling whilst little is known about the effect of other hormones on this part of the gut. What is known has been reviewed by Matthy and Noble (1972).

In a wide variety of diarrhoeal diseases faecal sodium concentration correlates very closely with faecal output (unpublished observations) reflecting the same close correlation found in colonic perfusion studies. Colonic absorptive function has been investigated in only a few such diseases, mainly ulcerative colitis and Crohn's disease. In these inflammatory diseases there is agreement that both the colon and rectum show a reduced capacity to absorb sodium and water (Duthie et al, 1964; Levitan and Brudno, 1967; Head, Heaton, and Kinel, 1969; Rask-Madsen, 1973; Edmonds and Pilcher, 1973). Increased potassium secretion also occurs (Archampong, Harris, and Clark, 1972; Harris and Shields, 1970). It is not yet clear whether this impaired ability to absorb sodium is due to a defect in the sodium 'pump', thus diminishing sodium insorption, or to increased mucosal permeability, or both. In studies of villous adenoma of the colon sodium secretion into the colonic lumen has been shown, suggesting that these tumour cells are different from the normal colonic mucosa (Duthie and Atwell, 1963; Shields, 1966). In chloridorrhoea chloride malabsorption both in the ileum and colon is the primary defect due to a failure of the $\mathrm{Cl} / \mathrm{HCO}_{3}$ exchange (Turnberg, 1971; Pearson et al, 1973; Bieberdorf, Gorden, and Fordtran, 1972). Increased sodium and water output are due to trapping of sodium in the colonic lumen by the chloride ion, with ammonium and hydrogen ion making up the cation deficit that occurs.

\section{Urea, Ammonia, and Nitrogen Metabolism}

Daily urea synthesis exceeds urea output in the urine by about $20 \%$. The difference is due to breakdown of urea in the intestine (Walser and Bodenlos, 1959). After the administration of intestinal antibiotics urea synthesis approximates more closely to urinary urea loss (Jones, Smallwood, Craigie, and Rosenoer, 1969). Thus between 6 and $9 \mathrm{~g}$ of urea, that is about $20 \%$ of daily urea synthesis, is catabolized in the gut each day. This process is thought to occur mainly in the colon and is due to the colonic microflora. The maximum amount of urea entering the colon each day from the ileum is about $0.4 \mathrm{~g}$ (Gibson, Sladen, and Dawson, 1973) and as there is no urea in faeces and only 1-3 m.mol of ammonia, its main metabolite (Wrong et al, 1965), almost all the 6-9 $\mathrm{g}$ of urea must be secreted into the colon each day, metabolized, and the metabolites absorbed. The capacity of the colon to absorb urea is minimal (Billich and Levitan, 1969; Wolpert, Phillips, and 
Summerskill, 1971). Urea is hydrolysed in the colonic lumen to ammonia and carbonic acid by bacterial urease, and this process may be inhibited by antibiotics (Evans, Aoyagi, and Summerskill, 1966; Wilson, Ing, Metcalfe-Gibson, and Wrong, 1968). Very little colonic mucosal urease activity is present in man (Aoyagi, Engstrom, Evans, and Summerskill, 1966) and its role in urea hydrolysis is probably small. Urea hydrolysis occurs in a juxtamucosal situation, as intravenously administered urea is metabolized more rapidly than urea perfused through the colonic lumen (Wolpert et al, 1971). The relative impermeability of the colonic mucosa to urea raises the possibility that small intestinal ureolysis may be important. Gibson et al (1973) have shown that urea breakdown in man continues in only slightly reduced amounts in ileostomists, and it is considerably increased in the stagnant loop syndrome (Jones et al, 1969). The small gut is much more permeable to urea than the colon and has slightly higher mucosal urease activity (Aoyagi et al, 1966).

If the colon is the main site for urea catabolism then 6-9 $\mathrm{g}$ of urea will give rise to 200-300 m.moles of ammonium and half as much bicarbonate each day. Ninety-nine per cent of the ammonia is absorbed across the mucosa by simple non-ionic diffusion (Castell and Moore, 1971 ; Bown, Sladen, Clark, and Dawson, 1971; Down et al, 1972). At colonic pH $(6 \cdot 0-7 \cdot 0)$ ammonia in present largely as the ammonium ion $\mathrm{NH}_{4}{ }^{+}$which may itself be absorbed when present at very high concentrations (Bown et $a l$, 1971). Supportive evidence for the non-ionic diffusion of ammonia comes from the close relationship between $\mathrm{pH}$ and ammonia absorption during colonic perfusion experiments and in the faeces (Down et al, 1972). As luminal pH falls so does ammonia absorption whilst faecal ammonia excretion rises as faecal $\mathrm{pH}$ falls. Wrong (1971) has suggested that ammonia absorption proceeds by coupled non-ionic diffusion in which bicarbonate and ammonium ions form ammonia and carbon dioxide which then diffuse freely across the mucosa, leaving no net change in either $\mathrm{pH}$ or ionic balance. The presence of bicarbonate in the colonic lumen facilitates ammonia absorption. Other parts of the gut handle ammonia in a similar way (Summerskill, 1970). In the hamster an active transport process may be present (Mossberg and Ross, 1967) although it is disputed (Price, Schwartz, Molavi, Britton, and Voorhees, 1967).

Microbial metabolism of urea is of major importance in animal nutrition (Stangell, 1967; Salter, 1973) but much less so in human nutrition. The absorbed ammonia is transported to the liver where it enters the nitrogen pool and is available for urea or amino acid synthesis. Ammonia is a more efficient source of nitrogen than urea for protein synthesis so that colonic metabolism of urea is an important step (Richards, 1972). When dietary protein is plentiful the contribution from non-protein nitrogen to protein synthesis is very small (Richards, MetcalfeGibson, Ward, Wrong, and Houghton, 1967) but this may increase to significant amounts and enable nitrogen balance to be maintained in malnutrition (Picou and Phillips, 1972) or during proteinrestrictive regimes in uraemia (Richards et al, 1967). The enterohepatic circulation of urea and ammonia is also of importance in the genesis of hepatic encephalopathy in liver disease.

\section{Organic Anion and Volatile Fatty Acids}

Organic anion is the major solute in faeces. Normal stools contain around 179 m-equiv/l (Rubinstein, Howard, and Wrong, 1969), an amount which far exceeds the concentration of any other compound. It is measured by titration in a similar way to that of organic anion in urine (Van Slyke and Palmer, 1920) and represents all the buffering between $\mathrm{pH} 2.7$ and 8.0, except that due to bicarbonate and phosphate. The anions which make up this major fraction of faeces have never been completely identified. The short-chain, or volatile, fatty acids (VFA), acetate, propionate, butyrate, etc, make up about $47 \%$, and a further $3 \%$ is made up of small quantities of a number of anions such as fumarate, lactate and succinate. The composition of the remaining $50 \%$ is unknown. The volatile fatty acids, of which acetate comprises about $60 \%$, are thus the major known component of organic anion and are important in colonic metabolism.

Only 1-3 m-equiv/l of volatile fatty acids are found in ileal fluid (Newton, Bennett, Billings, and MiltonThompson, 1972) whilst normal faeces contain 8090 m-equiv/l. In patients with diarrhoea volatile fatty acid output may rise to 160 m-equiv per day (Grove, Olmsted, and Koenig, 1929; Cummings, James, and Wiggins, 1973). They arise in the colon mainly from bacterial metabolism of unabsorbed dietary residues. Reduced amounts are found in the faeces after antibiotics and in 'germ-free' studies (Gompertz, Brooks, Gaya, and Spiers, 1973; Rubinstein et al, 1969). Diffusion through the colonic mucosa and other bacterial metabolism may contribute a small amount. How much volatile fatty acid is produced in the colon each day is unknown but it is almost certainly in excess of that found in the faeces. The metabolism of $10 \mathrm{~g}$ of dietary fibre, such as was observed by Southgate and Durnin (1971) in young men eating a diet containing wholemeal bread, could alone give rise to over 100 m-equiv of acetate per day. 
Volatile fatty acids have three possible fates in the colon. About $12 \mathrm{~m}$-equiv is excreted in the faeces each day, some may be metabolized by bacteria to $\mathrm{H}_{2}, \mathrm{CH}_{4}, \mathrm{H}_{2} \mathrm{O}$, and $\mathrm{CO}_{2}$ and some, possibly the largest proportion, are absorbed. In herbivores such as the rabbit the absorption of volatile fatty acids from the colon and caecum represents for them a major source of energy. Up to $22 \%$ of the rabbit's basal energy requirements come from absorbed volatile fatty acids, whilst the porcupine is able to absorb $83 \%$ produced in the caecum and $64 \%$ entering the colon (McBee, 1970). However, caecal pH is lower in herbivores than in man and absorption of volatile fatty acids in man has received only scant attention. Volatile fatty acids are absorbed in man in both the colon and small intestine by non-ionic diffusion. The rate of absorption is slow and dependent on the carbon chain length of the compound and the ambient $\mathrm{pH}$ (Dawson, Holdsworth, and Webb, 1964; Sallee and Dietschy, 1973). Longer chain length and low $\mathrm{pH}$ favour absorption. Active transport of volatile fatty acids (Smyth et al, 1957) is not now thought to occur but the availability of $\mathrm{H}^{+}$ may be important (Clarkson, Rothstein, and Cross, 1961). Volatile fatty acids in the rat colon stimulate salt and water absorption (Parsons, 1967). The contribution of absorbed volatile fatty acids to energy balance in man is small but may reach significant proportions where dietary fibre intake is high.

The increased excretion of organic anion and volatile fatty acids in diarrhoea has led to the suggestion that they play a major role in determining stool bulk (Fernandez, Gonzalez, Marzi, and Paolo, 1971; Torres-Pinedo, Lavastida, Rivera, Rodriguez, and Ortiz, 1966; Fordtran, 1971). The pK of the VFA is about 4.8 which means that at colonic pH they are virtually all present in the dissociated form. As absorption of such charged water-soluble molecules is very limited they will tend to accumulate in the lumen and cause an osmotic diarrhoea. However, the concentration of volatile fatty acids in the stools falls with increasingly severe diarrhoea, probably due to decreased colonic transit time in these patients allowing less time for their production (Cummings et al, 1973). It seems unlikely that the role of volatile fatty acids in diarrhoea in adults is anything other than passive.

\section{References}

Aoyagi, T., Engstrom, G. W., Evans, W. B., and Summerskill, W. H. J. (1966). Gastrointestinal urease in man. I. Activity of mucosal urease. Gut, 7, 631-635.

Archampong, E. Q., Harris, J., and Clark, C. G. (1972). The absorption and secretion of water and electrolytes across the healthy and the diseased human colonic mucosa measured in vitro. Gut, 13, 880-886.

Banwell, J. G., Gorbach, S. L., Pierce, N. F., Mitra, R., and Mondal, A. (1971). Acute undifferentiated human diarrhea in the tropics. II. Alterations in intestinal fluid and electrolyte move- ments. J. clin. Invest., 50, 890-900.

Banwell, J. G., Pierce, N. F., Mitra, R. C., Brigham, K. L., Caranasos, G. J., Keimowitz, R. I., Fedson, D. S., Thomas, J., Gorbach, S. L., Sack, R. B., and Mondal, A. (1970). Intestinal fluid and electrolyte transport in human cholera. J. clin. Invest., 49, 183-195.

Barry, R. J. C., and Smyth, D. H. (1960). Transfer of short-chain fatty acids by the intestine. J. Physiol. (Lond.), 152, 48-66.

Bieberdorf, F. A., Gorden, P., and Fordtran, J. S. (1972). Pathogenesis of congenital alkalosis with diarrhea. J. clin. Invest., 51, 19581968.

Billich, C. O., and Levitan, R. (1969). Effects of sodium concentration and osmolality on water and electrolyte absorption from the intact human colon. J. clin. Invest., 48, 1336-1347.

Binder, H. J., and Rawlins, C. L. (1972). Neutral or coupled $\mathrm{NaCl}$ absorption in the colon. (Abstr.) Gastroenterology, 62, 839.

Bown, R. L., Sladen, G. E., Clark, M. L., and Dawson, A. M. (1971). The production and transport of ammonia in the human colon. (Abstr.) Gut, 12, 863.

Bown, R. L., Sladen, G. E., Rousseau, B., Gibson, J. A., Clark, M. L., and Dawson, A. M. (1972). A study of water and electrolyte transport by the excluded human colon. Clin. Sci., 43, 891-902.

Carter, M. J., and Parsons, D. S. (1968). Carbonic anhydrase activity of mucosa of small intestine and colon. Nature (Lond.), 219, 176-177.

Castell, D. O., and Moore, E. W. (1971). Ammonia absorption from the human colon. Gastroenterology, 60, 33-42.

Charron, R. C., Leme, C. E., Wilson, D. R., Ing, T. S., and Wrong, O. M. (1969). The effects of adrenal steroids on stool composition, as revealed by in vivo dialysis of feces. Clin. Sci., 37, 151-167.

Clarkson, T. W., Rothstein, A., and Cross, A. (1961). Transport of monovalent anions by isolated small intestine of the rat. Amer. J. Physiol., 200, 781-788.

Cummings, J. H., James, W. P. T., and Wiggins, H. S. (1973). The role of the colon in ileal-resection diarrhoea. Lancet, 1, 344-34n.

Cummings, J. H., Milton-Thompson, G. J., Billings, J., Newman, A., and Misiewicz, J. J. (1974). Studies on the site of production of diarrhoea induced by prostaglandins. (Abstr.) Clin. Sci., 46, $15 P$.

Davies, N. T., Munday, K. A., and Parsons, B. J. (1970). The effect of angiotensin on rat intestine fluid transfer. $J$. Endocr., 48, 39-46.

Dawson, A. M., Holdsworth, C. D., and Webb, J. (1964). Absorption of short chain fatty acids in man. Proc. Soc. exp. Biol. (N.Y.), 117, 97-100.

Devroede, G. J., and Phillips, S. F. (1969). Conservation of sodium, chloride and water by the human colon. Gastroenterology, 56, 101-109.

Devroede, G. J., Phillips, S. F., Code, C. F., and Lind, J. F. (1971). Regional differences in rates of insorption of sodium and water from the human large intestine. Canad. J. Physiol. Pharmacol., 49, 1023-1029.

Down, P. F., Agostini, L., Murison, J., and Wrong, O. M. (1972). The interrelations of fecal ammonia, $\mathrm{pH}$ and bicarbonate: evidence of colonic absorption of ammonia by non-ionic diffusion. Clin. Sci., 43, 101-114.

Duthie, H. L., and Atwell, J. D. (1963). The absorption of water, sodium, and potassium in the large intestine with particular reference to the effects of villous papillomas. Gut, 4, 373-377.

Duthie, H. L., Watts, J. M., de Dombal, F. T., and Goligher, J. C. (1964). Serum electrolytes and colonic transfer of water and electrolytes in chronic ulcerative colitis. Gastroenterology, 47, 525-530.

Edmonds, C. J. (1971). Absorption of sodium and water by human rectum measured by a dialysis method. Gut, 12, 356-362.

Edmonds, C. J., and Godfrey, R. C. (1970). Measurement of electrical potentials of the human rectum and pelvic colon in normal and aldosterone-treated patients. Gut, 11, 330-337.

Edmonds, C. J., and Marriott, J. C. (1967). The effect of aldosterone and adrenalectomy on the electrical potential difference of rat colon and the transport of sodium, potassium, chloride and bicarbonate. J. Endocr., 39, 517-531.

Edmonds, C. J., and Pilcher, D. (1972). Sodium transport mechanisms of the large intestine. In Transport Across the Intestine: $A$ Glaxo Symposium, edited by W. L. Burland and P. D. Samuel, pp. 43-57. Churchill Livingstone, Edinburgh and London.

Edmonds, C. J., and Pilcher, D. (1973). Electrical potential difference and sodium and potassium fluxes across rectal mucosa in ulcerative colitis. Gut, 14, 784-789. 
Edmonds, C. J., and Richards, P. (1970). Measurement of rectal electrical potential difference as an instant screening test for hyperaldosteronism. Lancet, 2, 624-627.

Elmslie, R. G., Mulholland, A. T., and Shields, R. (1966). Blocking by spironolactone (SC9420) of the action of aldosterone upon the intestinal transport of potassium, sodium and water. Gut, 7, 697-699.

Evans, W. B., Aoyagi, T., and Summerskill, W. H. J. (1966). Gastrointestinal urease in man. II. Urea hydrolysis and ammonia absorption in upper and lower gut lumen and the effect of neomycin. Gut, 7, 635-639.

Fernandez, L. B., Gonzalez, E., Marzi, A., and Paolo, M. I. L. (1971). Fecal acidorrhea. New Engl. J. Med., 284, 295-298.

Fordtran, J. S. (1971). Organic anions in fecal contents. New Engl. J. Med., 284, 329-330.

Gazet, J. C. (1968). The surgical significance of the ileo-caecal junction. Ann. roy. Coll. Surg. Engl., 43, 19-38.

Gibson, J. A., Sladen, G. E., and Dawson, A. M. (1973). Studies in the role of the colon in urea metabolism. (Abstr.) Gut, 14, 816.

Giller, J., and Phillips, S. F. (1972). Electrolyte absorption and secretion in the human colon. Amer.J. dig. Dis., 17, 1003-1011.

Gingell, J. C., Davies, M. W., and Shields, R. (1968). Effects of a synthetic gastrin-like pentapeptide upon the intestinal transport of sodium, potassium and water. Gut, 9, 111-116.

Gompertz, D., Brooks, A. P., Gaya, H., and Spiers, A. S. D. (1973), Volatile fatty acids in the faeces of patients in 'germ-free' isolation. Gut, 14, 183-186.

Grady, G. F., Duhamel, R. C., and Moore, E. W. (1970). Active transport of sodium by human colon in vitro. Gastroenterology, 59, 583-588.

Grove, E. W., Olmsted, W. H., and Koenig, K. (1929). The effect of diet and catharsis on the lower volatile fatty acids in the stools of normal men. J. biol. Chem., 85, 127-136.

Harris, J., and Shields, R. (1970). Absorption and secretion of water and electrolytes by the intact human colon in diffuse untreated proctocolitis. Gut, 11, 27-33.

Head, L. H., Heaton, J. W., Jr., and Kivel, R. M. (1969). Absorption of water and electrolytes in Crohn's disease of the colon. Gastroenterology, 56, 571-579.

Hornych, A., Meyer, P., and Milliez, P. (1973). Angiotensin, vasopressin, and cyclic AMP: effects on sodium and water fluxes in rat colon. Amer. J. Physiol., 224, 1223-1229.

Johnson, G. K., Soergel, K. H., Hensley, G. T., Dodds, W. J., and Hogan, W. J. (1972). Cronkhite-Canada syndrome: gastrointestinal pathophysiology and morphology. Gastroenterology, 63, 140-152.

Jones, E. A., Smallwood, R. A., Craigie, A., and Rosenoer, V. M. (1969). The enterohepatic circulation of urea nitrogen. Clin. Sci., 37, 825-836.

Kanaghinis, T., Lubran, M., and Coghill, N. F. (1963). The composition of ileostomy fluid. Gut, 4, 322-338.

Kuriaki, K., and Magee, D. F. (1964). On the carbonic anhydrase activity of the alimentary canal and pancreas. Life Sci., 3, 1377-1382.

Levitan, R. (1967). Salt and water absorption from the normal human colon: effect of $9 a$-fluorohydrocortisone administration. J. Lab. clin. Med., 69, 558-564.

Levitan, R., and Brudno, S. (1967). Permeability of the recto-sigmoid mucosa to tritiated water in normal subjects and in patients with mild idiopathic ulcerative colitis. Gut, 8, 15-19.

Levitan, R., Fordtran, J. S., Burrows, B. A., and Infelfinger, F. J. (1962). Water and salt absorption in the human colon. J. clin. Invest., 41, 1754-1759.

Levitan, R., and Ingelfinger, F. J. (1965). Effect of $\delta$-aldosterone on salt and water absorption from the intact human colon. $J$. clin. Invest., 44, 801-808.

Levitan, R., and Mauer, I. (1966). The influence of pitressin administration on salt and water absorption from the human colon (Abstr.) Clin. Res., 14, 301.

McBee, R. H. (1970). Metabolic contributions of the cecal flora. Amer. J. clin. Nutr., 23, 1514-1518.

Maren, T. H. (1967). Carbonic anhydrase: chemistry, physiology and inhibition. Physiol. Rev., 47, 595-781.

Matthy, A. S., and Noble, H. M. (1972). Hormones and water movement through the vertebrate intestine. Hormones, (Basel) 3 , 42-64.

Mossberg, S. M., and Ross, G. (1967). Ammonia movement in the small intestine: preferential transport by the ileum. $J$. clin. Invest., 46, 490-498.
Newton, C. A., Bennett, A. N., Billings, J. A., and Milton-Thompson, G. J. (1972). Ileal short chain fatty acid concentrations after a chemically defined meal (Abstr.) Arch. Mal. Appar. dig., 61, $37 c$.

Parsons, D. S. (1967). Salt and water absorption by the intestinal tract. Brit. med. Bull., 23, 252-257.

Parsons, B. J., and Munday, K. A. (1972). The action of angiotensin on sodium and fluid transport. In Transport Across the Intestine: A Glaxo Symposium, edited by W. L. Burland and P. D. Samuel, pp. 59-70. Churchill Livingstone, Edinburgh and London.

Pearson, A. J. G., Sladen, G. E., Edmonds, C. J., Tavill, A. S., Wills, M. R., and McIntyre, N. (1973). The pathophysiology of congenital chloridorrhoea. Quart. J. Med., 42, 453-466.

Phillips, S. F. (1969). Absorption and secretion by the colon. Gastroenterology, 56, 966-971.

Phillips, S. F., and Giller, J. (1973). The contribution of the colon to electrolyte and water conservation in man. J. Lab. clin. Med., 81, 733-746.

Picou, D., and Phillips, M. (1972). Urea metabolism in malnourished and recovered children receiving high or low protein diet. Amer. J. clin. Nutr., 25, 1261-1266.

Powell, D. W., and Malawer, S. J. (1968). Relationship between water and solute transport from isosmotic solutions by rat intestine in vivo. Amer. J. Physiol., 215, 49-55.

Price, J. B., Jr., Schwartz, G. F., Molavi, A., Britton, R. C., and Voorhees, A. B., Jr. (1967). Mechanism and clinical significance of intestinal ammonia transport. Surg. Forum, 18, 331-333.

Rask-Madsen, J. (1973). Simultaneous measurement of electrical polarization and electrolyte transport by the entire normal and inflamed human colon during in vivo perfusion. Scand. J. Gastroent., 8, 327-336.

Rask-Madsen, J., Hammersgaard, E. A., and Knudsen, E. (1973). Rectal electrolyte transport and mucosal permeability in ulcerative colitis and Crohn's disease. J. Lab. clin. Med., 81, 342-353.

Richards, P. (1969). Clinical investigation of the effects of adrenal corticosteroid excess on the colon. Lancet, 1, 437-442.

Richards, P. (1972). Nutritional potential of nitrogen re-cycling in man. Amer. J. clin. Nutr., 25, 615-625.

Richards, P., Metcalfe-Gibson, A., Ward, E. E., Wrong, O. M., and Houghton, B. J. (1967). Utilisation of ammonia nitrogen for protein synthesis in man, and the effect of protein restriction and uraemia. Lancet, 2, 845-849.

Rubinstein, R., Howard, A. V., and Wrong, O. M. (1969). In vivo dialysis of faeces as a method of stool analysis. IV. The organic anion component. Clin. Sci., 37, 549-564.

Sallee, V. L., and Dietschy, J. M. (1973). Determinants of intestinal mucosal uptake of short and medium chain fatty acids and alcohols. J. Lipid Res., 14, 475-484.

Salter, D. N. (1973). The influence of gut micro-organisms on utilisation of dietary protein. Proc. nutr. Soc., 32, 65-71.

Shields, R. (1966). Absorption and secretion of electrolytes and water by the human colon, with particular reference to benign adenoma and papilloma. Brit. J. Surg., 53, 893-897.

Shields, R. (1972). Absorption and secretion by human colon. In Recent Advances in Gastroenterology, edited by J. Badenoch and B. N. Brooke, pp. 215-249. Churchill Livingstone, Edinburgh and London.

Shields, R., and Miles, J. B. (1965). Absorption and secretion in the large intestine. Postgrad. med. J., 41, 433-439.

Shields, R., Miles, J. B., and Gilbertson, C. (1968). Absorption and secretion of water and electrolytes by the intact colon in a patient with primary aldosteronism. Brit. med. J., 1, 93-96.

Shields, R., Mulholland, A. T., and Elmslie, R. G. (1966). Action of aldosterone upon the intestinal transport of potassium, sodium and water. Gut, 7, 686-696.

Sladen, G. E. G. (1972). A review of water and electrolyte transport. In Transport Across the Intestine: A Glaxo Symposium, edited by W. L. Burland and P. D. Samuel, pp. 14-34. Churchill Livingstone, Edinburgh and London.

Soergel, K. H. (1971). Flow measurements of test meals and fasting contents in the human small intestine. In Gastrointestinal Motility, edited by L. Demling and R. Ottenjann, pp. 81-95. Thieme, Stuttgart.

Southgate, D. A. T., and Durnin, J. V. G. A. (1970). Calorie conversion factors: an experimental re-assessment of the factors used in the calculation of the energy value of human diets. Brit. $J$. Nutr., 24, 517-535.

Stangel, H. J. (1967). History of the use of urea in ruminant feeds. In 
Urea as a Protein Supplement, edited by M. H. Briggs, pp. 3-32. Pergamon Press, Oxford.

Summerskill, W. H. J. (1970). Ammonia metabolism in the gastrointestinal tract. In Progr. Gastroent 276-287.

Torres-Pinedo, R., Lavastida, M., Rivera, C. L., Rodriguez, H., and Ortiz, A. (1966). Studies on infant diarrhea. I. A composition of the effects of milk feeding and intravenous therapy on the composition and volume of the stool and urine. J. clin. Invest., 45, 469-480.

Turnberg, L. A. (1970). Electrolyte absorption from the colon. Gut, 11, 1049-1054.

Turnberg, L. A. (1971). Abnormalities in intestinal electrolyte transport in congenital chloridorrhoea. Gut, 12, 544-551.

Turnberg, L. A., Bieberdorf, F. A., Morawski, S. G., and Fordtran, J. S. (1970). Interrelationships of chloride, bicarbonate, sodium, and hydrogen transport in the human ileum. J. clin. Invest., 49, 557-567.

Van Slyke, D. D., and Palmer, W. W. (1920). Studies of acidosis. XVI. The titration of organic acids in urine. J. biol. Chem., 41, 567. 585 .

\section{The March 1975 Issue}

\section{THE MARCH 1975 ISSUE CONTAINS THE FOLLOWING PAPERS}

The immediate and delayed effects of different types of vagotomy on human gastric myoelectrical activity C. J. STODDARD, R. SMALLWOOD, B. H. BROWN, AND H. L. DUTHIE

An assessment of the reproducibility and safety of 2-deoxy-D-glucose as a gastric acid stimulant in duodenal ulcer patients A. L. GOUGH AND N. C. KEDDIE

Serum pyridoxal in active peptic ulceration C. $\mathbf{R}$. SANDERSON AND R. E. DAVIS

Red cell abnormalities associated with sulphasalazine maintenance therapy for ulcerative colitis R. E. POUNDER, E. R. CRAVEN, JOAN S. HENTHORN, AND J. MELINDA BANNATYNE

The effect of histamine $\mathrm{H}_{2}$-receptor blockade with metiamide on serum gastrin levels in man G. 0 . BARBEZAT, B. GRANT, S. BANK, AND A. VINIK

Iron absorption in normal subjects and patients with idiopathic haemochromatosis: Relationship with serum ferritin concentration G. O. WALTERS, A. JACOBS, M. WORWOOD, D. TREVETT AND W. THOMSON

The effect of tea on iron absorption P. B. DISLER, S. R. LYNCH, R. W. CHARLTON, J. D. TORRANCE, T. H. BOTHWELL, R. B. WALKER, AND FATIMA MAYET

Changes in the bidirectional sodium flux across the intestinal mucosa in Crohn's disease ROBERT ALLAN, D. M. STEINBERG, K. DIXON, AND W. T. COOKE
Walser, M., and Bodenlos, L. J. (1959). Urea metabolism in man. J. clin. Invest., 38, 1617-1626.

Wilson, D. R., Ing, T. S., Metcalfe-Gibson, A., and Wrong, O. M. (1968). The chemical composition of taeces in uraemia, as revealed by in-vivo faecal dialysis. Clin. Sci., 35, 197-209.

Wingate, D. L., Krag, E., Mekhjian, H. S., and Phillips, S. F. (1973). Relationships between ion and water movement in the human jejunum, ileum and colon during perfusion with bile acids. Clin. Sci., 45, 593-606.

Wolpert, E., Phillips, S. F., and Summerskill, W. H. J. (1971). Transport of urea and ammonia production in the human colon. Lancet, 2, 1387-1390.

Wrong, O. M. (1968). Aldosterone and electrolyte movements in the colon. Brit. med. J., 1, 379-380.

Wrong, O. M. (1971). The role of the human colon in homeostasis. Sci. Basis Med. Ann. Revi, pp. 192-215.

Wrong, O. M., Metcalfe-Gibson, A., Morrison, R. B. I., Ng, S. T., and Howard, A. V. (1965). In vivo dialysis of faeces as a method of stool analysis. I. Techniques and results in normal subjects. Clin. Sci., 28, 357-375.
A study of the cellular infiltrate of the proximal jejunal mucosa in ulcerative colitis and Crohn's disease R. FERGUSON, R. N. ALLAN, AND W. T. COOKE

The effect of wheat bran on intestinal transit D. $\mathrm{K}$. PAYLER, E. W. POMARE, K. W. HEATON, AND R. F. HARVEY

Influence of azathioprine on hepatic reserve in chronic active liver disease LAYTON RIKKERS AND SHEILA SHERLOCK

Liver ultrastructure in Gilbert's syndrome J. O'D. MCGEE, J. G. ALLAN, R. I. RUSSELL, AND R. S. PATRICK

Complete identification of endocrine cells in the gastrointestinal tract using semithin-thin sections to identify motilin cells in human and animal intestine JULIA M. POLAK, A. G. E. PEARSE, AND CATHERINE M. HEATH

Lipodystrophy, pancreatitis, and eosinophilia P. M. SMITH, M. E. MORGANS, C. G. CLARK, AND J. E. LENNARD-JONES, AND OLAFUR GUNNLAUGSSON, AND TOMAS A. JONASSON

\section{Progress report}

Gastric emptying tests in man H. J. SHEINER

Notes and activities

Copies are still available and may be obtained from the PUBLISHING MANAGER, BRITISH MEDICAL ASSOCIATION, TAVISTOCK SQUARE, LONDON, WC1H 9JR, price $£ 2.00$, including postage 